\title{
Effects of Zero Tillage and Residue Retention on Soil Quality in the Mediterranean Region of Northern Syria
}

\author{
Rolf Sommer ${ }^{*}$, Colin Piggin ${ }^{2}$, David Feindel' ${ }^{2}$, Muhammad Ansar ${ }^{2}$, Lona van Delden², \\ Kayoko Shimonaka², Jihad Abdalla², Osama Douba', George Estefan², Atef Haddad2, \\ Rousheen Haj-Abdo², Ali Hajdibo², Pierre Hayek2, Yaseen Khalil2, Ahmed Khoder², \\ John Ryan ${ }^{2}$ \\ ${ }^{1}$ International Center for Tropical Agriculture, CIAT, Nairobi, Kenya \\ ${ }^{2}$ International Center for Agricultural Research in the Dry Areas (ICARDA), Aleppo, Syria \\ Email: ${ }^{*}$ r.sommer@cgiar.org
}

Received 27 January 2014; revised 27 February 2014; accepted 8 March 2014

Copyright (C) 2014 by authors and Scientific Research Publishing Inc.

This work is licensed under the Creative Commons Attribution International License (CC BY).

http://creativecommons.org/licenses/by/4.0/

(c) (i) Open Access

\begin{abstract}
Zero-tillage (ZT) and crop residue retention on the soil surface- two components of Conservation Agriculture (CA) - have been identified as promising management practices for sustainable agricultural intensification for some time. However, CA technology uptake by farmers in the dry areas of West Asia and North Africa (WANA) has yet to happen large-scale, even though the positive impact on yield has been demonstrated repeatedly. To explain the observed consistent increases in crop yield under ZT, a range of soil quality indicators were regularly monitored during 2008 to 2012 in the long-term ZT/CA trials at the headquarters of the International Center for Agricultural Research in the Dry Areas (ICARDA) in northern Syria. Results showed that CA had a positive impact on soil fertility. This was measurable by higher soil organic matter (SOM) and microbial biomass contents, increased levels of extractable phosphate, sometimes (but not always) higher amounts of larger water-stable soil aggregates, increased soil infiltration capacity and soil water retention. The buildup of SOM and associated carbon (C) sequestration was in the range of $0.29 \mathrm{Mg}$ C/ha/yr, i.e. rather modest. High amounts of surface residues delayed the desiccation of the topsoil during the fallow period, but could not diminish the overall longer-term drying of the topsoil. The observed positive changes in soil quality were little, but nevertheless, in combination with the economic savings that ZT offers, this type of agricultural intensification provides an attractive option for farmers in WANA, from the standpoints of economy and ecological efficiency.
\end{abstract}

\section{Keywords}

Conservation Agriculture; Soil Fertility Indicators; Soil Water Evaporation; Water Infiltration;

\footnotetext{
${ }^{*}$ Corresponding author.
}

How to cite this paper: Sommer, R., et al. (2014) Effects of zero tillage and residue retention on soil quality in the Mediterranean region of northern Syria. Open Journal of Soil Science, 4, 109-125.

http://dx.doi.org/10.4236/ojss.2014.43015 


\section{Water Stable Aggregates; Soil Carbon Sequestration}

\section{Introduction}

The Mediterranean region has been cultivated for millennia and is the site of the evolution of settled agriculture and the center of origin of a range of important crops [1]. Over the centuries, soils have been slowly but continuously degraded by removal of nutrients in harvest products, by intensive grazing and/or soil erosion. Adverse climatic conditions of variable and frequently inadequate rainfall and a long dry season characteristic to the Mediterranean climate render the region's landscape vulnerable to over-exploitation and further degradation [2].

In recent decades, agricultural production has intensified in the Mediterranean region, especially the increase with continuous cropping instead of fallow and application of mineral fertilizer. To mitigate the negative impact of such intensification, various management practices have been developed, such as rotations as an alternative to mono-cropping [3], reduced tillage or no/zero tillage (NT, ZT) instead of conventional tillage (CT) [4] [5], the production and use of compost from manure, straw and other organic residues [6] or development of fertilizer best management practices [7]. In a major shift from conventional production systems, conservation agriculture (CA) systems, embracing ZT for minimal soil disturbance, surface residue retention and crop rotation, have been adopted extensively in Australia, Canada, the USA and Latin America [8] [9]. This development has been driven by labor and energy savings, control of soil erosion, better soil moisture conservation [10] [11] [12] and the opportunity for earlier sowing and better yields. In addition to soil conservation, CA systems in the majority of cases have been shown to increase the amount of soil organic matter (SOM), which improves soil quality and the environmental sustainability of agro-ecosystems. The build-up of SOM involves sequestration of carbon (C), which may contribute to mitigation of increasing atmospheric $\mathrm{CO}_{2}$ levels [13], even though the potential contribution may be limited [14] [15].

Uptake of CA by farmers in the Mediterranean region is lagging behind uptake elsewhere in the world, even in countries such as Morocco and Tunisia where considerable research has been done [16]. Only during the last few years some progress has been achieved [5]. Retention of residues in agro-ecosystems where livestock play an important role is a potential obstacle to CA adoption. In the Mediterranean region of West Asia and North Africa (WANA), sheep and goats are an integral part of farming systems [17]-[19] and crop residues are a crucial part of small ruminant's diet, especially during the dry season [20] [21].

To address some of these issues, the International Center for Agricultural Research in the Dry Areas (ICARDA) has carried out experiments on-station or demonstrations with farmers, to test ZT and residue retention and their impact on crop yield [5]. Few studies have been published so far focusing on soils of the Mediterranean region and how they are affected by ZT/CA practices [6] [21]-[23]. Therefore, in the long-term ZT/CA trials at ICARDA's headquarters at Tel Hadya in Syria, a range of soil quality indicators were regularly monitored during 2008 to 2012, to help explain increases in crop yields that were observed under the various ZT systems. The study also sought to identify suitable indicators of increased soil quality, and quantify the amount of C that can be sequestered under partial residue retention and the impact of surface residue on soil moisture conservation and soil water evaporation.

\section{Material and Methods}

\subsection{Location}

The experimental fields were located at ICARDA headquarters, Tel Hadya, $30 \mathrm{~km}$ south of Aleppo in northern Syria $\left(36.011^{\circ} \mathrm{N} 36.931^{\circ} \mathrm{E}, 285 \mathrm{~m}\right.$ above sea level). The climate is semiarid with an average annual temperature of $17.8^{\circ} \mathrm{C}$. Details of the station and its role in technology development and transfer in the WANA region have been recently described by [7]. The rainfall pattern is typical Mediterranean (rain from October until May), with an annual (1980-2011) average of $334 \mathrm{~mm}$. The rainfed cropping season usually begins in November and extends to May-June. Wheat (Triticum aestivum), barley (Hordeum vulgare), chickpea (Cicer arietinum) and lentil (Lens culinaris) are the main rainfed crops in the region.

The main soils of the region have been classified as Vertisols, Inceptisols, and Aridisols [24], and are gener- 
ally low in SOM, nitrogen $(\mathrm{N})$ and plant-available phosphorus $(\mathrm{P})$, have a clay texture $(60 \%-70 \%)$, and are highly calcareous $\left(\sim 20 \% \mathrm{CaCO}_{3}\right)$. The soil at Tel Hadya has been classified as a very fine, montmorillonitic, thermic, Chromic Calcixerert [24]. The montmorillonite clay minerals expand when wet and shrink when dry and the alternate shrinking and swelling cause some moderate self-mulching. Soil water infiltration rates and saturated hydraulic conductivity are moderate to low when the soil is wet.

\subsection{Experimental Fields and Their Management}

ICARDA has maintained three long-term CA experiments at Tel Hadya, termed B4, B7 and C16 trials (Figure 1).

\subsubsection{B4}

In the B4 trial, the effects of tillage (CT vs ZT) and early and late planting were tested in a four-course rotation of wheat, chickpea, barley, and lentil. The trial was initiated in 2006/07 in a split plot design with tillage as main plots and crops as sub plots; the trial was further split into time of sowing (early vs late) sub-sub plots in 2008/ 09; there were four replications and a plot size of $780 \mathrm{~m}^{2}$.

The barley-lentil-wheat-chickpea rotation treatment was duplicated so as to have each crop present in the field each year. CT comprised moldboard ploughing after cereals and disk ploughing after legumes soon after harvest in June or July, and a second tillage by a tine cultivator before sowing in the autumn. ZT comprised sowing directly into uncultivated stubble, with pre-sowing control of weeds (Glyphosate) usually only necessary on late-sown plots. All plots were sown with a ZT seeder. Early planting was undertaken after the first germinating rains (early-mid November) and late planting about 4 weeks later (early-mid December). Crops received basal fertilizer, i.e. $150 \mathrm{~kg} / \mathrm{ha}$ di-ammonium phosphate $\left(18 \% \mathrm{~N}, 46 \% \mathrm{P}_{2} \mathrm{O}_{5}\right)$ for cereals and $150 \mathrm{~kg} / \mathrm{ha}$ triple superphosphate $\left(46 \% \mathrm{P}_{2} \mathrm{O}_{5}\right)$. Cereals received an additional $40 \mathrm{~kg} / \mathrm{ha}$ urea $(46 \% \mathrm{~N})$ around tillering 2 - 3 months after sowing. Post-emergence weeds were controlled with selective herbicides as necessary.

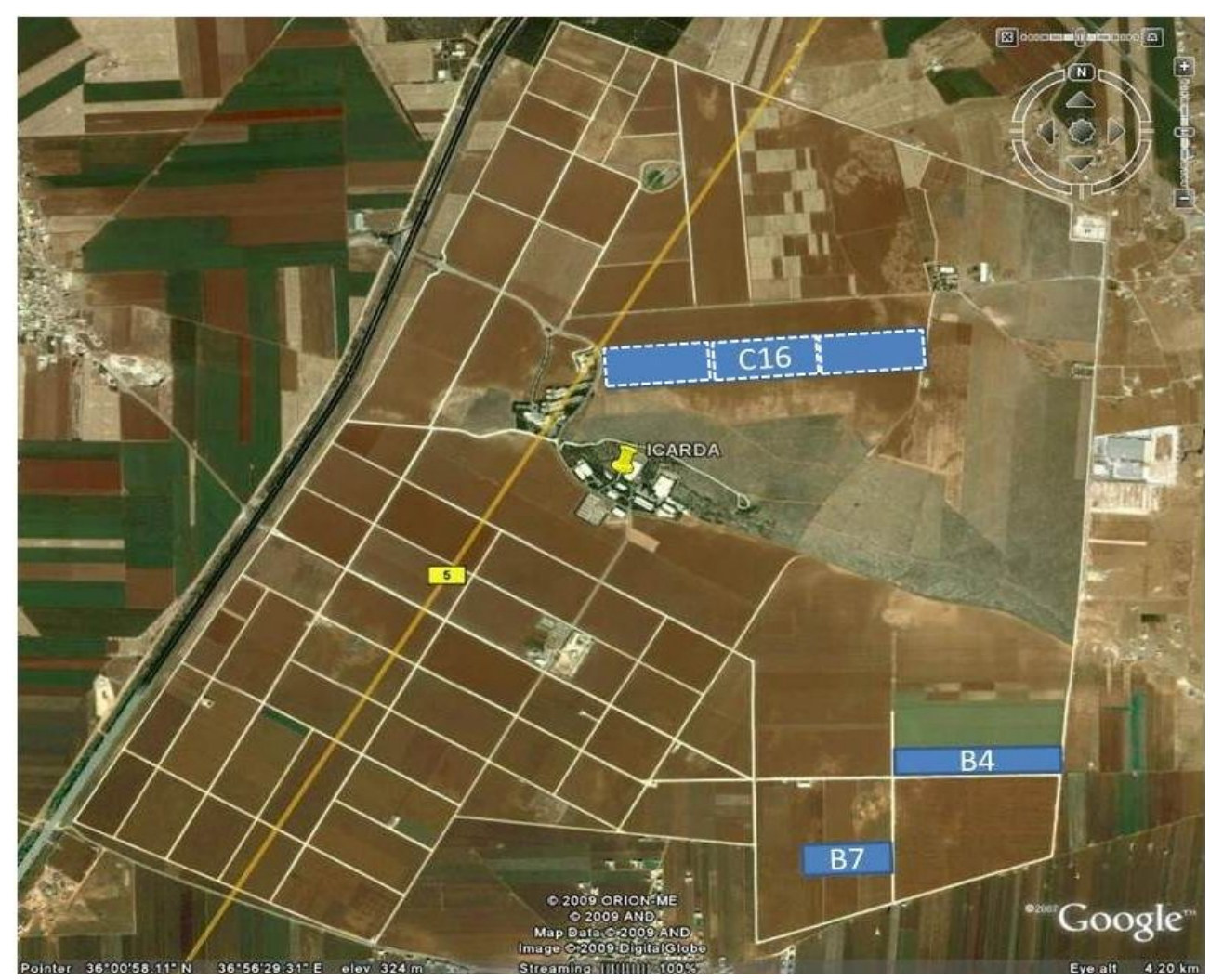

Figure 1. Google Earth image of ICARDA headquarters in northern Syria and location of the three main conservation agriculture trials (C16, B4 and B7); dotted sub-plots in C16 indicate the three blocks of this trial (1-3 from west to east); the network of research station fields and roads is clearly visible. 


\subsubsection{B7}

The B7 trial was laid out in a split-split plot design with four replications and a plot size of $120 \mathrm{~m}^{2}$ and a total of 112 plots. Established in 1998, the trial had three treatments: wheat-legume crop rotation, different levels of land preparation by tillage, and plus/minus $\mathrm{N}$-fertilizer application. Seven different tillage practices were tested, which furthermore differed depending on whether wheat or a legume had been the preceding crop. Only four tillage treatments were considered in this study, mainly to reduce sample size but also because for the remaining three tillage treatments a different drilling machine-a conventional seeder with different row spacing rather than a direct drill/ZT seeder-was used, which could have confounded the results. In the chosen Tillage treatment No. 2, tillage and seed bed preparation for wheat and the legumes were done by a cultivator and $1-2$ passes with a sweeper. Crop residues were chopped and spread after harvest, i.e. retained on the plots. Tillage treatment No. 4 was equal to No. 2, except that wheat residues were incorporated into the soil with a moldboard plough and the plots were then rolled and levelled with a sweeper once, before planting of legumes. Tillage treatment No. 6 was ZT plus residue retention (full CA) and No. 7 was ZT without residue retention. Planting and fertilizer application was done as in B4.

\subsubsection{C16}

This experiment was established in 2006/07 to study the impact of tillage (CT vs ZT) on growth and yield in a flexible rotation of the common cereal and legume crops (wheat, barley, lentil, chickpea) in the region. Tillage main plots were split into time of planting (early vs late) sub plots in 2007/08 and these were further split into residue $(\mathrm{R})$ management $\left(\mathrm{R}+=\right.$ residue retained; $\mathrm{R}^{-}=$residue partly removed) sub-sub plots in 2008/09. The experiment was thus a split-split plot design with three replications, with a total of 24 plots each 0.5 ha in area. The CT Late $\mathrm{R}$ - treatment was similar to what farmers practice in the region, whereas the ZT Early $\mathrm{R}+$ treatment represented the land-conserving land management practice recommended by the ICARDA agronomists and soil scientist.

The crop sequence from 2006/07 to 2011/12 was wheat, lentil, barley, wheat, lentil and wheat. Crops were established and managed as described under B4 above. The cereal residue management was as follows: on the $\mathrm{R}+$ plots at harvest, cereal plants were harvested as high as possible and stubble and loose residues were fully retained. On the $\mathrm{R}-$ plots cereals were harvested as low as possible and loose residues were baled and removed from the field, with short stubbles and the non-baled fraction of loose straw retained in the field, which made Ra partial residue removal treatment. In lentil years (2010/11) all straw was removed in the hand harvesting operation.

\subsection{Measurements}

\subsubsection{Long-Term Trials}

To assess changes in soil quality in response to tillage, residue retention, N-fertilizer application and crop rotation, a range of soil quality indicators were measured. A comprehensive description of the applied methods for chemical and physical analyses is given in [25]. At the onset of the 5 years of measurements, in September 2008, soil bulk density was measured in excavated soil pits ( $\mathrm{n}=3$ per trial) next to the trials by undisturbed core sampling in 10-cm intervals from 5 to $85 \mathrm{~cm}$ and $105 \mathrm{~cm}$.

The first soil sampling of treatments was carried out on 28 October 2008, a few days before (early) planting. A total of $n=10, n=4$ and $n=3$ sub-samples was taken at $0-25,25-60$ and $60-100 \mathrm{~cm}$ depth respectively and mixed to get one composite sample per depth. Samples were taken in the CT and ZT late-planted wheat plots of B4, all considered plots of B7, and all plots with full residue retention $(\mathrm{R}+)$ of plot $\mathrm{C} 16$. These samples were subject to analysis of soil texture, $(1 \mathrm{~N}$ ammonium acetate) extractable potassium (K), plant-available mineral $\mathrm{N}$ distinguished into ammonium- $\mathrm{N}$ and nitrate-N, $0.5 \mathrm{M}$ sodium bicarbonate extractable (Olsen) P, and SOM.

This soil sampling was repeated on 11 March, 29 April, 13 July 2009 and January 2010 (C16 only) to assess seasonal trends of mineral N. This was repeated in the early planted plots of C16 in March 2010 with composite soil samples ( $n=3$ sub-samples) taken at depth increments of $0-5,5-10$ and $10-25 \mathrm{~cm}$, to detect possible differences with depth. Similarly, extractable P analysis was repeated in December 2009 in C16 at 0 - 25, 25 60 and $60-100 \mathrm{~cm}$ depths.

SOM sampling was undertaken in February 2012 in the early-planted plots of B4, with soil samples taken at 0 - 10 and 10 - 30 cm depths. In March 2010, SOM at very fine depth increments (0 - 2, 2 - 5, 5 - 10 cm depth), 
was studied by [26] [27] in the CT Early R- and ZT Early R- treatments of C16. SOM was assessed once again in C16 in September 2011 at $0-10 \mathrm{~cm}$ and $10-25 \mathrm{~cm}$ depths, with sample numbers increased to 8 per plot to ac- count for field SOM heterogeneity and increase the chances to even small differences; these samples were taken at CT Late R- plots and ZT Early R+ plots, the two treatments that were assumed to show largest differences, the first reflecting farmer's practice, the latter researchers' best bet.

As bacterial biomass is considered a more sensitive indicator of soil change than gross chemical measurements, the $\mathrm{C}$ and $\mathrm{N}$ contents in the soil microbial biomass were measured in April 2009 in soil samples from 0 $25 \mathrm{~cm}$ depth in the late planted plots of B4 and the Late R+ plots of C16.

Water stable soil aggregates (WSAs) were measured in April 2009 at $0-25 \mathrm{~cm}$ depth from ZT and CT plots of B4 and C16 (early planting only), and in February 2012 in the early-planted plots of B4, with samples taken at $0-10 \mathrm{~cm}$ and $10-25 \mathrm{~cm}$ depth. Field fresh soil (50 g) was put on two stacked sieves with mesh-widths of 0.5 $\mathrm{mm}$ and $0.2 \mathrm{~mm}$. The sieves were then inundated in water, wet-sieved (motorized equipment with constant number of strokes/min.) for 30 sec., and the remaining soil in each sieve, the WSA, was weighted. Results were expressed in per cent abundance of WSAs in the different size classes.

Soil water infiltration was measured in C16 eight times over a period of 1.5 years, i.e. 28 October and 28 December 2010, 2 February, 15 March, 3 April, 6 October and 28 November 2011 and 18 March 2012. In studying infiltration, we were interested in comparing ZT with CT plots, assuming that planting date would have little or no effect on soil physical properties. At each time, three infiltration measurements were made on each of the late-planted plots following [28] using a falling-head, single-ring infiltrometer. Infiltration records (fluxes) were then corrected by an analytical formula that compensates for the non-constant falling head and for the subsurface radial water spread. The authors claim that this provides consistent records corresponding to saturated hydraulic conductivity $\left(\mathrm{K}_{\mathrm{s}}\right)$. We used a fixed value for the macroscopic capillary length, $\lambda$, equal to $0.08 \mathrm{~m}$, as suggested by [28] for fine-textured soils.

In February 2012, undisturbed, $100 \mathrm{~cm}^{3}$ ring cores samples $(\mathrm{n}=24)$ were taken at $0-5 \mathrm{~cm}$ depth in the late-planted plots of B4 for analysis of soil water retention (SWR) curves. The SWR method involved stepwise water drainage imposed via a (max. $1 \mathrm{~m}$ ) hanging water column attached to a sandbox on top of which the samples are placed, repeated measurement of the weight of the samples, and subsequent calculation of corresponding water content using the weight of the soil after oven-drying and its known volume.

\subsubsection{Surface Residue Retention and Soil Water Evaporation}

To study the impact of different levels of surface residue retention on soil water evaporation and topsoil water content under wheat after conventional tillage land preparation, a one-factorial field trial (randomized plot design with four reps) was initiated in 2010. Surface residue in the form of loose wheat straw was applied at the beginning of April into the standing wheat crop at six different levels, i.e. 0 (bare soil), 1.5, 3, 4.5, 6 and 7.5 t/ha. On 20 April 2010, the whole experiment was irrigated with a boom sprinkler at a rate of $30 \mathrm{~mm}$; two days later, soil moisture determination started. Measuring intervals were gradually increased, from daily to weekly. Wheat on all plots was harvested at the end of May. On 28 June, the harvested plots were irrigated once again with 30 $\mathrm{mm}$ and soil moisture monitored under fallow conditions, i.e., eliminating transpiration and focusing on evaporation only. Soil moisture was determined either by TDR probe (TRIME; $15 \mathrm{~cm}$ rod length; factory calibrated) at $0-15 \mathrm{~cm}$ depth (five replications per plot) or manually at $0-15$ and $15-30 \mathrm{~cm}$.

\subsection{Statistical Analysis}

Statistical analysis of the results was undertaken with GenStat 14. To account for the interdependency of soil properties, the different soil depths were considered as repeat measures in the ANOVA.

\section{Results}

\subsection{Soil Texture, Extractable Potassium and Bulk Density}

The texture of the soils of the B4, B7 and C16 sites was clay throughout. With depths the clay content significantly increased by approximately $10 \%$ units (least significant difference $[\mathrm{LSD}]=1.5 \%$ ). Sites differed significantly in clay (LSD $=4 \%)$, partly in silt (LSD $=3 \%$ ) and sand content $(\mathrm{LSD}=2 \%)$.

The extractable K concentration was high in all depths and sites (Table 1) and significantly different amongsites and depths (LSD site $=11 \mathrm{mg} / \mathrm{kg}$; LSD depth $=15 \mathrm{mg} / \mathrm{kg}$ ). 
Table 1. Average texture and extractable potassium at 0 - 25, 25 - 60 and $60-100 \mathrm{~cm}$ depth in the B4, B7 and C16 trials (soil sampling Oct. 2008).

\begin{tabular}{ccccc}
\hline & Site & $\mathbf{0 - 2 5} \mathbf{~ c m}$ & $\mathbf{2 5} \mathbf{- 6 0} \mathbf{~ c m}$ & $\mathbf{6 0}-\mathbf{1 0 0} \mathbf{~ c m}$ \\
\hline \multirow{3}{*}{ Clay (\%) } & B4 & 65 & 70 & 76 \\
& B7 & 58 & 62 & 64 \\
& C16 & 62 & 66 & 71 \\
Silt (\%) & B4 & 31 & 26 & 22 \\
& B7 & 34 & 29 & 30 \\
Sand (\%) & C16 & 25 & 23 & 22 \\
& B4 & 4 & 4 & 2 \\
& B7 & 9 & 9 & 7 \\
Extractable K (mg/kg) & C16 & 12 & 11 & 116 \\
& B4 & 272 & 157 & 145 \\
\hline
\end{tabular}

Soil bulk density varied amongsites, with the top $50 \mathrm{~cm}$ significantly lower in C16 than in B4 and B7 (LSD site $=0.1 \mathrm{~g} / \mathrm{cm}^{3}$; Figure 2).

\subsection{Plant-Available Mineral Nitrogen}

Ammonium-N concentrations at 0 - 25, 25 - 60 and 60 - $100 \mathrm{~cm}$ depth, with on average 5 - $12 \mathrm{mg} / \mathrm{kg}$ in 0 - 25 $\mathrm{cm}$ and less than $3 \mathrm{mg} / \mathrm{kg}$ in $25-100 \mathrm{~cm}$, were highest at the beginning of the 2008/09 cropping season in October 2008 in all plots and depths, as expected in response to rapid mineralization of organic matter after some first light rains. This ammonium was then quickly transformed into nitrate, with nitrate concentrations between on average 8 and $20 \mathrm{mg} / \mathrm{kg}$, but highly variable throughout. A translocation of nitrate from the top to the bottom layer towards March was visible in all plots. Subsequently, nitrate- $\mathrm{N}$ was depleted in response to plant uptake, most pronounced in C16 (nitrate- $\mathrm{N}<4 \mathrm{mg} / \mathrm{kg}$ in all depth and treatments). CT treatments could not be significantly distinguished from ZT treatments, as variation of results was very high. Likewise, none of the other treatments had any significant impact on mineral $\mathrm{N}$ concentrations.

January 2010 sampling revealed that none of the factors tillage, residue management and planting date had a significant effect on ammonium or nitrate content in C16. Ammonium- $\mathrm{N}$ was less than $1.5 \mathrm{mg} / \mathrm{kg}$ at all depths, and nitrate concentrations slightly reduced with depth from 6 to $4 \mathrm{mg} / \mathrm{kg}$.

Sampling in March 2010 at depths of $0-5,5-10$ and $10-25 \mathrm{~cm}$ also revealed no significant differences among treatments.

\subsection{Extractable Phosphate}

Topsoil $(0-25 \mathrm{~cm})$ extractable P was significantly higher under the corresponding ZT treatment in B4, B7 and C16 compared to treatments 2 and 4 of B7, or the CT treatments of the B4 and C16, repeatedly during the measuring period (Figure 3).

The increases in extractable P in response to ZT were not large, and sometimes not significant (B4 and C16, Oct. 2008) due to the considerable variability of results, but nevertheless pointed towards a basic improvement of fertility under ZT, reflected in higher extractable P contents. Surprisingly, in B7, straw residue removal (Treatment No. 6) did not negatively affect extractable P in comparison to Treatment No. 7 where straw was retained. Likewise, the $\mathrm{N}$-treatment (plus and minus $\mathrm{N}$ fertilizer application) in $\mathrm{B} 7 \mathrm{did}$ not affect the results significantly. The positive impact of ZT in B4 was only measurable in the top $10 \mathrm{~cm}$ of the soil.

\subsection{Soil Organic Matter}

Differences in SOM in 0 - $25 \mathrm{~cm}$ and deeper soil depths were small in October 2008 and could not be attributed to any of the applied treatments in B4 and C16. However, C16 had significantly higher SOM contents in 0 - 25 $\mathrm{cm}$ than B4. In B7, N fertilizer application significantly $(\mathrm{p}=0.048)$ increased SOM contents averaged across the 


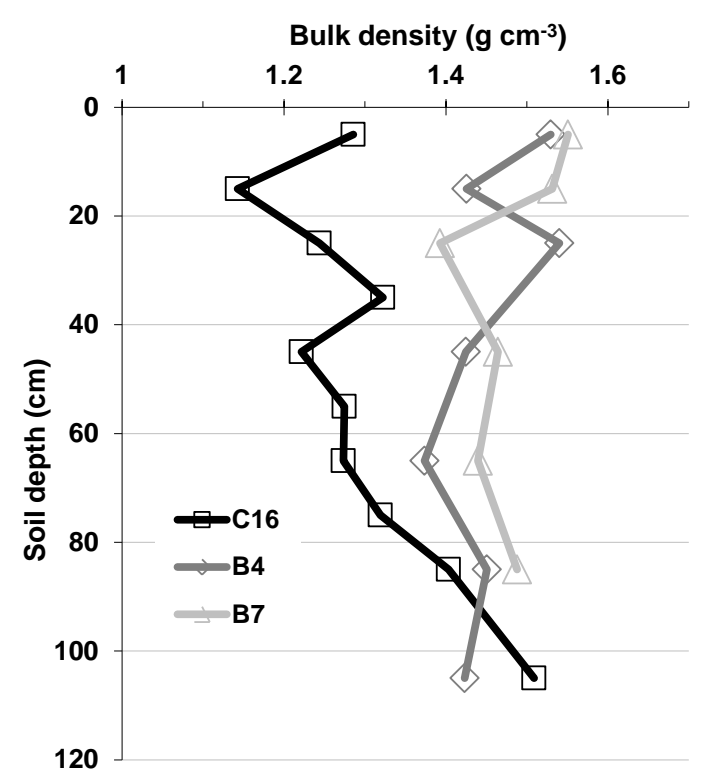

Figure 2. Soil bulk density at various depths in the B4, B7 and C16 trials; soil sampling Sept. 2008.

three depths (N+: $0.92 \%, \mathrm{~N}-: 0.88 \%$, LSD: $0.04 \%$; Figure 4, top left). Assuming an average soil bulk density of $1.3 \mathrm{~g} / \mathrm{cm} 3$, the application of $\mathrm{N}$-fertilizer increased the top $1 \mathrm{~m}$ SOM amount in B7 by $4.9 \mathrm{Mg} / \mathrm{ha}(\mathrm{N}-:$ : 114.6 , $\mathrm{N}+: 119.5 \mathrm{Mg} / \mathrm{ha}$ ) over a period of 10 years, i.e. a notable annual addition of almost $0.5 \mathrm{Mg} / \mathrm{ha}$, and corresponding to a soil organic carbon amount of $0.29 \mathrm{Mg} / \mathrm{ha}$.

The assessment of topsoil SOM in C16 in very fine depth-increments in March 2010 revealed that ZT significantly increased SOM contents in $0-2 \mathrm{~cm}$ depth as compared to CT (LSD tillage $=0.3 \%$; Figure 4), with the same (but not significant) trends at $2-5$ and $5-10 \mathrm{~cm}$. SOM was measured in the R-plots, which means that retention of only part of the residues on top of the soil under ZT rather than ploughing them into the soil under CT provided a benefit in terms of increased SOM.

The intensive soil sampling in September 2011 in C16 comparing CT Late R- and ZT Early R+ was supposed to take care of the variability of SOM in the field. The results, surprisingly, revealed that the SOM in C16 had a pronounced west-east gradient (Figure 4), witnessed by a significant impact of the trial's blocks, which were aligned west to east (Figure 1). It is likely that this gradient is because of edaphic reasons, i.e. a result of soil forming processes that in the historic past led to higher biomass production and subsequent organic matter input into the western part of the field. This is because similar yield gradients attributable to the trial's blocks that could have supported the argument that such gradients developed only after the onset of the long-term experiment have not been detected. Nevertheless, disentangled by blocks, tillage had a significant impact on SOM in general, and in particular at $0-10 \mathrm{~cm}$ in Block 1 and 2, and $10-25 \mathrm{~cm}$ in Block 2. At $0-25 \mathrm{~cm}$ and across all blocks the difference in organic carbon of ZT and CT amounted to $1.38 \mathrm{Mg} /$ ha over 5 years (2006/07-2010/11). The annual (linear) C-sequestration rate in response to the adoption of ZT, early planting and residue retention as opposed to CT, late planting and partial residue removal, would thus be $0.28 \mathrm{Mg} / \mathrm{ha}$.

\subsection{Soil Microbial Biomass}

The microbial $\mathrm{C}$ and $\mathrm{N}$ contents in soil samples from 0-25 cm depth in the Late R+ plots of C16 were significantly higher than in the soil samples from ZT and CT late-planted plots of B4 (LSD site, C-content $=19 \mathrm{mg} / \mathrm{kg}$, LSD site, $\mathrm{N}$-content $=4 \mathrm{mg} / \mathrm{kg}$ ). The microbial C content varied greatly, and no differences among tillage treatments could be observed. However, tillage had a significant impact on microbial N in B4, with ZT increasing microbial N content (Figure 5). No such impact could be observed in C16.

\subsection{Water-Stable Soil Aggregates}

In April 2009, ZT significantly increased the percent WSA > 0.5 mm in B4 (Figure 6, top). Both trials, B4 and 


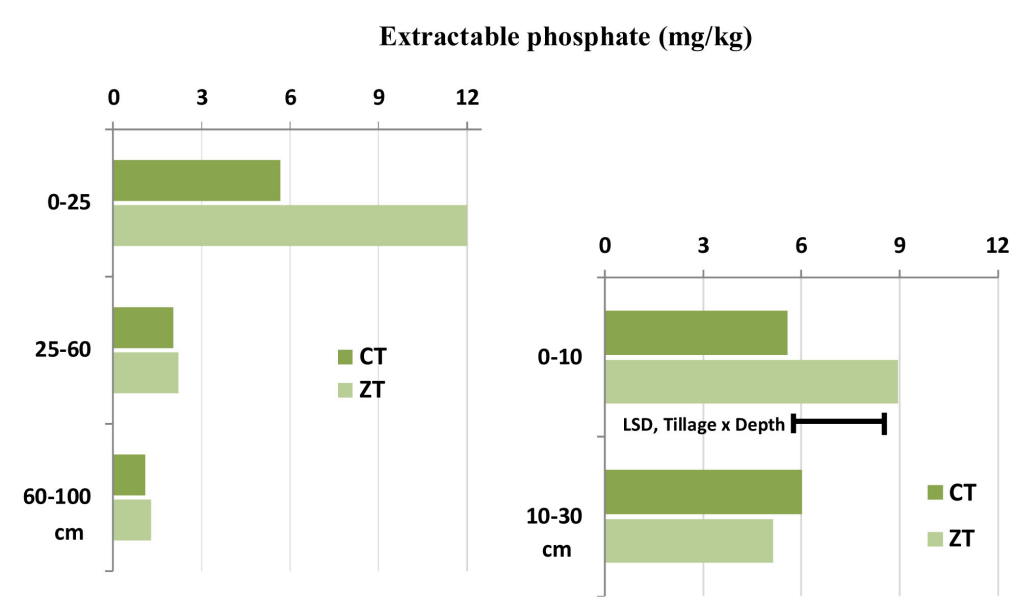

B7, Oct. 2008

C16, Oct. 2008

C16, Dec. 2009

Extractable phosphate (mg/kg)
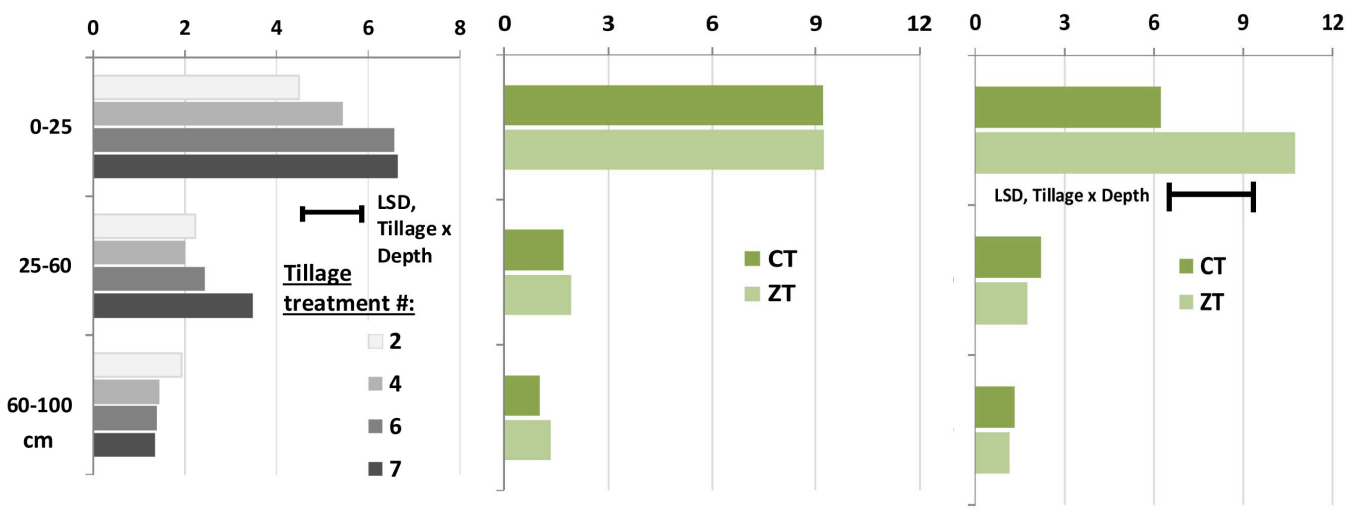

Figure 3. Extractable (Olsen) phosphate measured in the B4, B7 and C16 trials, in Oct. 2008, Dec. 2009 and Feb. 2012; LSDs Tillage $\times$ Depth: B4, Feb. $2012=2.7$ mg/kg, B7, Oct. $2008=1.3 \mathrm{mg} / \mathrm{kg}$, C16, Dec. 2009 $=2.7 \mathrm{mg} / \mathrm{kg}$ ).

C16, had significantly less WSA in the $0.2-0.5 \mathrm{~mm}$ class under ZT. C16 had significantly more large $(>0.5 \mathrm{~mm})$ WSAs than B4, irrespectively of the method of soil tillage.

In February 2012, WSA determination in B4 was repeated, at depths of $0-10 \mathrm{~cm}$ and $10-25 \mathrm{~cm}$. There was a tendency towards a higher percentage of large WSA under ZT at $0-10 \mathrm{~cm}$, but the impact was not significant (Figure 6, bottom). Likewise, crop had no impact. Topsoil $(0-10 \mathrm{~cm})$ and sub-soil $(10-25 \mathrm{~cm})$ differed significantly in terms of per cent WSA for all aggregate classes. At $10-25 \mathrm{~cm}$ depth, contrary to the April 2009 observations, CT significantly increased the per cent WSA in the $>0.5 \mathrm{~mm}$ class and decreased WSAs in the 0.5 $0.2 \mathrm{~mm}$ and $<0.2 \mathrm{~mm}$ classes.

\subsection{Soil Water Infiltration, Hydraulic Conductivity}

C16 ZT plots consistently had a higher hydraulic conductivity than CT plots, with the exception of December 2010 (Figure 7). Differences were significantly different, except for October 2010 and March 2011. We assume that in December 2010 the impact of tillage (loosening of the soil) that had been carried out before planting at the end of November, was still measurable, as this season was exceptionally dry with only little rainfall that could diminish such tillage impact. The positive impact of ZT was statistically significant. Likewise, however, also time of sampling had a significant impact on hydraulic conductivity. Especially when the soil was dry (October), hydraulic conductivity was lower than during the rainy season (November-April). 


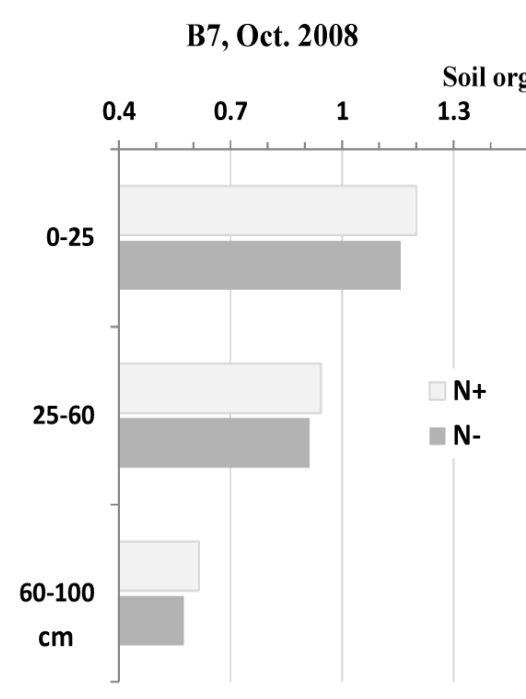

Block 1

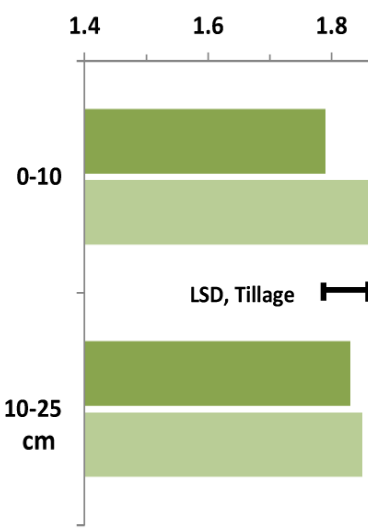

C16, Mar.2010

Soil organic matter (\%)

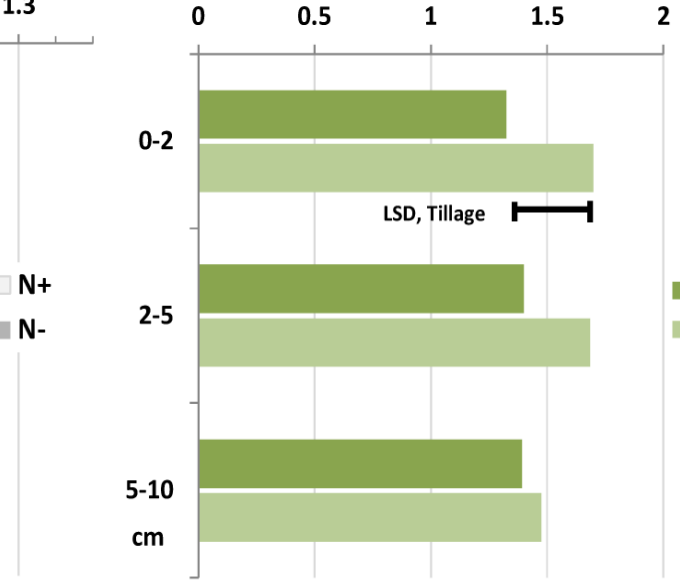

CT, Early Planting, R-

ZT, Early Planting, R-

C16, Sept. 2011

Block 2

Soil organic matter (\%)

21.
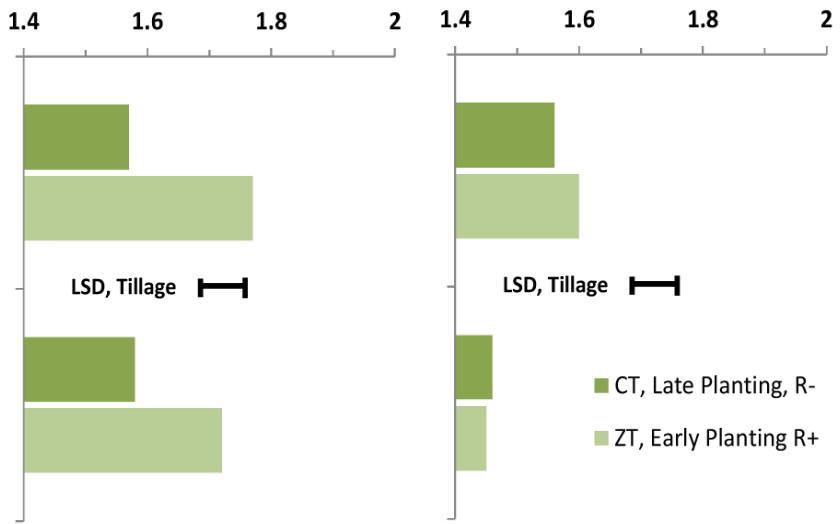

Figure 4. Soil organic matter (\%) measured in October 2008 in the B7 (top left, LSD Nitrogen = $0.04 \%$ ), in Mar. 2010 (top right, LSD Tillage $=0.3 \%$ ) and in September 2011 in the C16 trial distinguished by trial blocks (bottom).

B4

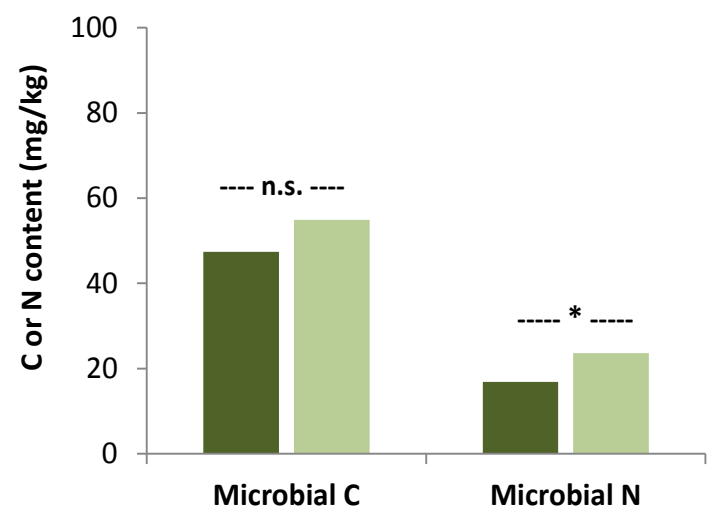

C16

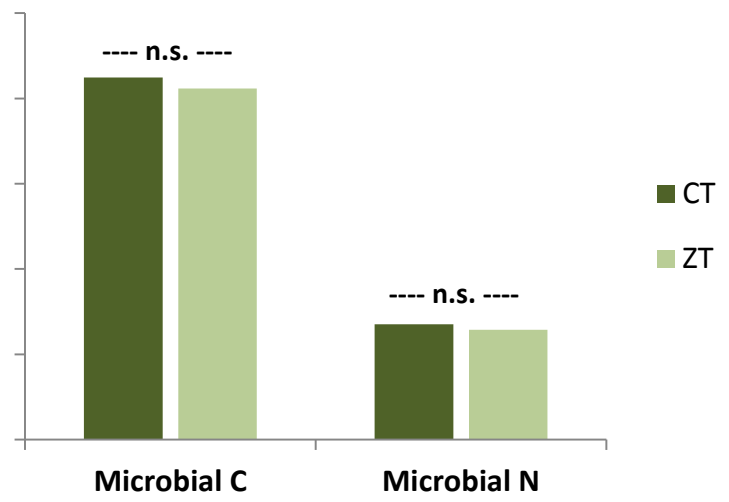

Figure 5. Microbial C and N content measured in April 2009 under CT and ZT plots of ICARDA's long-term trials B4 (left) and C16 (right); LSD, B4, Microbial N = $3 \mathrm{mg} / \mathrm{kg}$. 


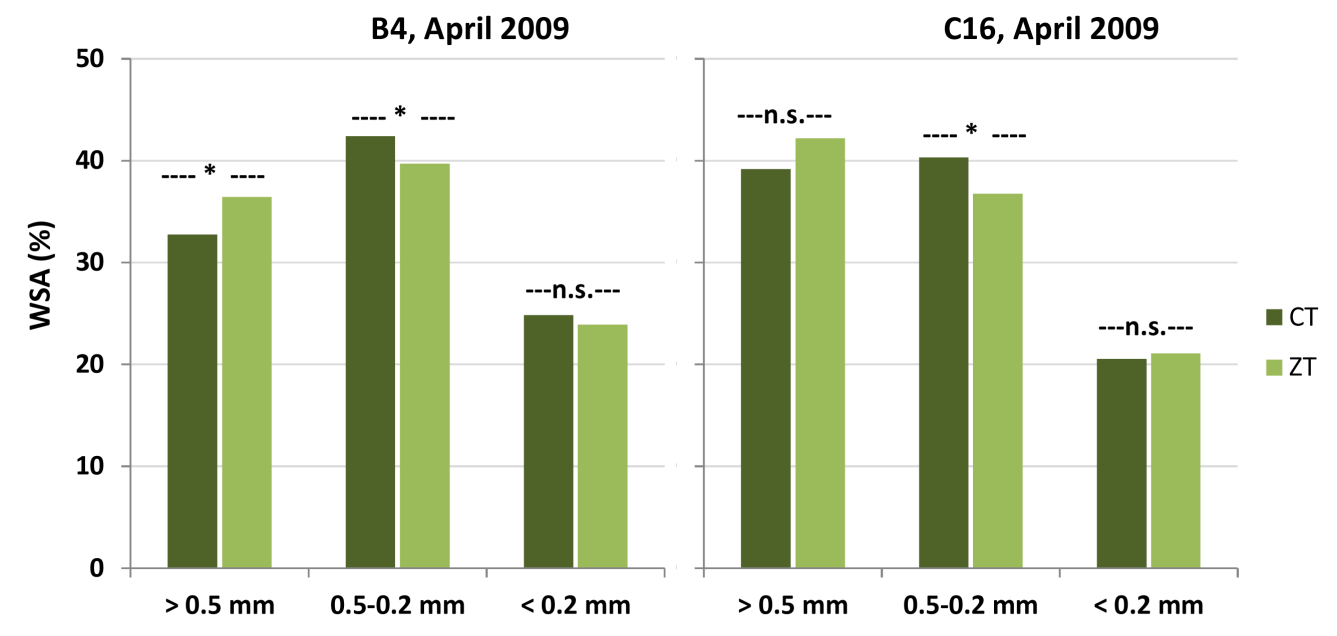

B4, Feb. 2012

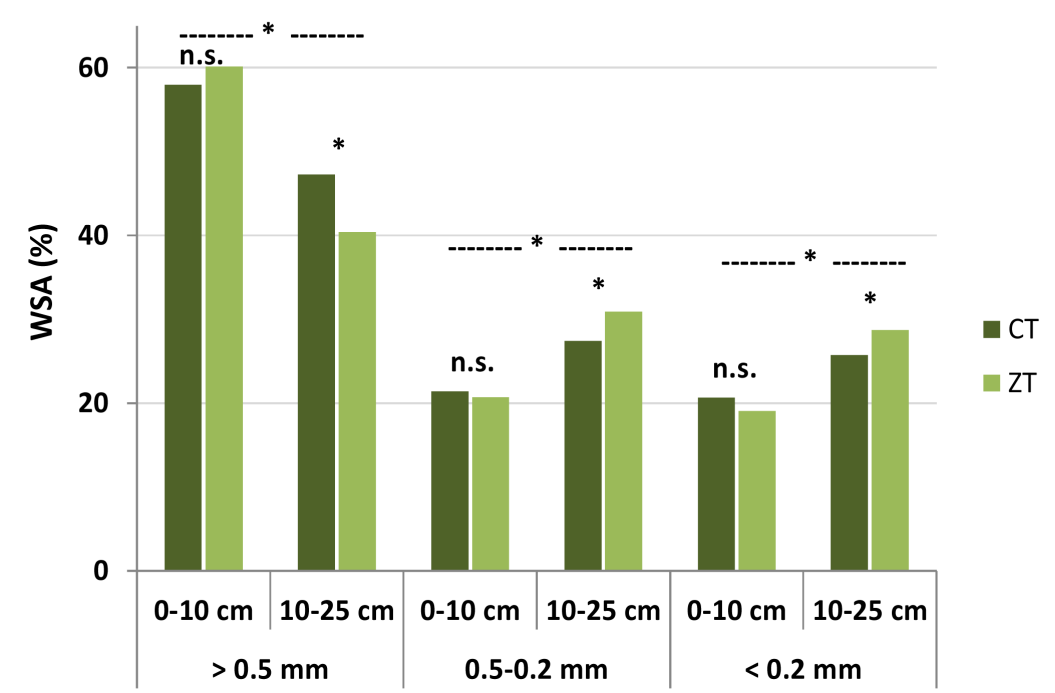

Figure 6. Water-stable aggregates by aggregate size class of soil taken April 2009 at 0 - $25 \mathrm{~cm}$ depth, and February 2012 at $0-10 \mathrm{~cm}$ and $10-25 \mathrm{~cm}$ depth in ZT and CT plots of the B4 and C16 trial.

\subsection{Soil Water Retention}

At all applied soil water pressure heads, soil samples from the ZT plots of B4 at $0-5 \mathrm{~cm}$ depth had higher water contents than samples from the CT plots. The overall tillage effect was significant because of the significant differences between $\mathrm{ZT}$ and $\mathrm{CT}$ water contents at $-1 \mathrm{~cm}(\mathrm{pF} 0=$ saturation) and $-2.5 \mathrm{~cm}(\mathrm{pF} 0.4)$ pressure head (Figure 8).

\subsection{Surface Residue Retention and Soil Water Evaporation}

Soil moisture determination during the late part of the wheat cropping season and following the application of $30 \mathrm{~mm}$ of irrigation water did not reveal a significant influence of the varying residue levels on moisture depletion by transpiration and evaporation. Different levels of residue application also did not have an effect on grain yields - as expected, because the residue layers were only applied in April. However, comparing yields averaged across all residue treatments with yields of a neighboring non-irrigated field with the same wheat crop, managed in the same way until the experiment started, the impact of $30 \mathrm{~mm}$ of irrigation on wheat grain yield was significant $(\mathrm{LSD}=0.371 \mathrm{t} / \mathrm{ha}$ ), with $1.642 \mathrm{t} / \mathrm{ha}$ under non-irrigated conditions and $2.015 \mathrm{t} / \mathrm{ha}$ under irrigated conditions average across the all residue levels. 


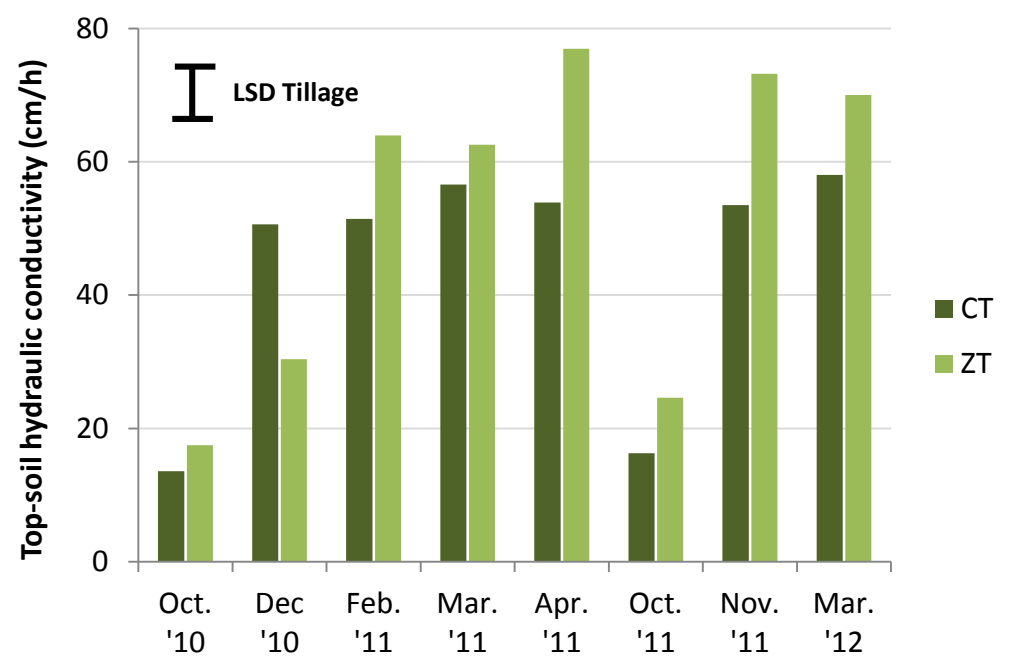

Figure 7. Topsoil hydraulic conductivity $(\mathrm{cm} / \mathrm{h})$ of $\mathrm{CT}$ and ZT plots of the $\mathrm{C} 16$ trial over the period Oct. 2010 to March 2012.

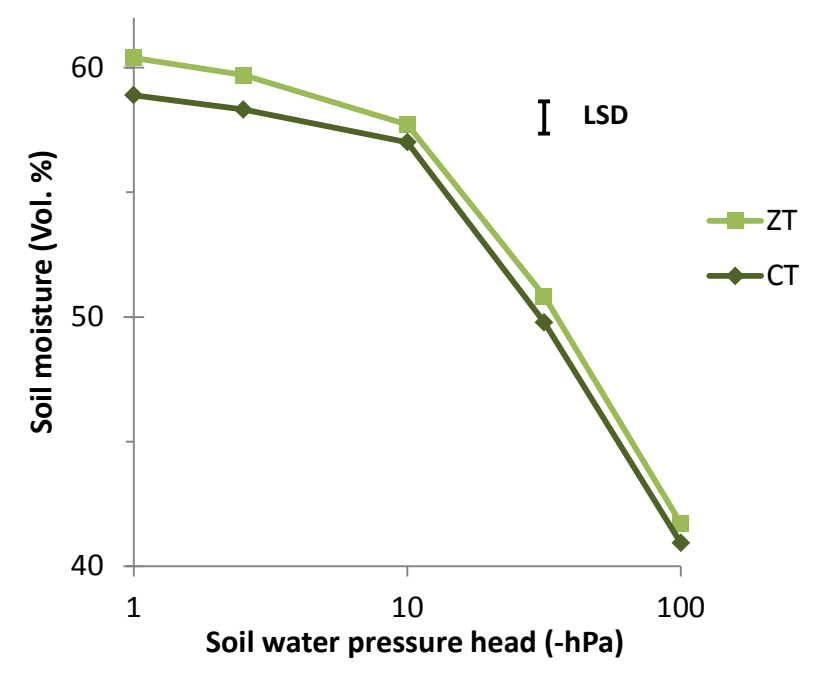

Figure 8. Soil water retention curves of undisturbed soil samples from ZT and CT plots of the B4 trial.

As was the case for the in-season observations, soil moisture dynamics measured after harvest under fallow conditions at 0 - $15 \mathrm{~cm}$ depth were not affected by the residue treatments (Figure 9). However, there was a tendency for higher soil moisture contents during the first three weeks following application of $30 \mathrm{~mm}$ of water 28 June, under the two highest residue retention treatments (6 and $7.5 \mathrm{t} / \mathrm{ha}$ ).

On 5 August, when soil moisture was measured by gravimetric sampling at $0-15 \mathrm{~cm}$ and $15-30 \mathrm{~cm}$ depth, surface residue retention amounts had a significant impact on total water amounts (mm/30 cm depth) when combining the two sampling depths (Figure 10). With increasing amounts of residues retained soil moisture in the $0-30 \mathrm{~cm}$ depth increased. Applying $7.5 \mathrm{t} / \mathrm{ha}$ straw residues on the surface significantly increased soil moisture compared to the bare soil control and the lowest level of residue retention (1.5 t/ha).

\section{Discussion}

High extractable K concentrations are common for the calcaric soils of the Mediterranean region and $\mathrm{K}$ is generally not yield limiting and also not applied as mineral fertilizer. The "baseline" assessment in October 2008 confirmed $\mathrm{K}$ was not limiting in the trial sites; the observed significant differences among the three experiments were considered to be most likely due to edaphic reasons. Higher topsoil bulk densities in the B4 and B7 trials 


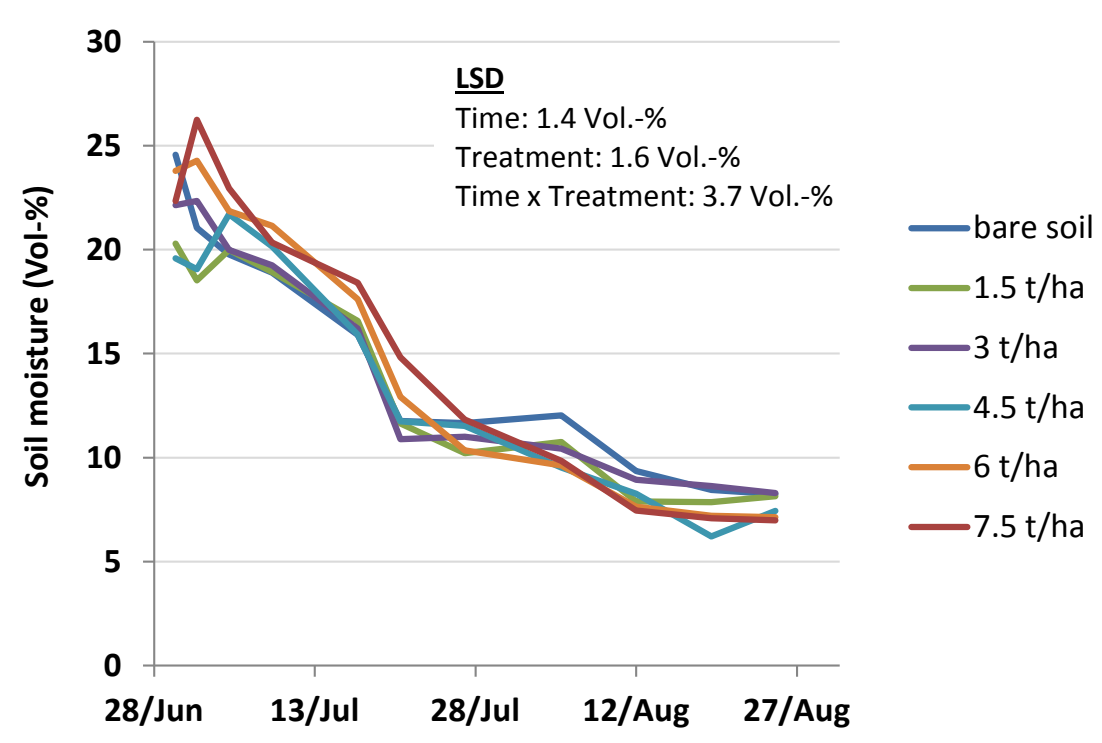

Figure 9. Soil moisture dynamics at 0 - $15 \mathrm{~cm}$ soil depth under fallow plots with varying levels of surface residue retention in 2010 and application of $30 \mathrm{~mm}$ of irrigation 28 June; all observations by TDR except gravimetric sampling 5 August

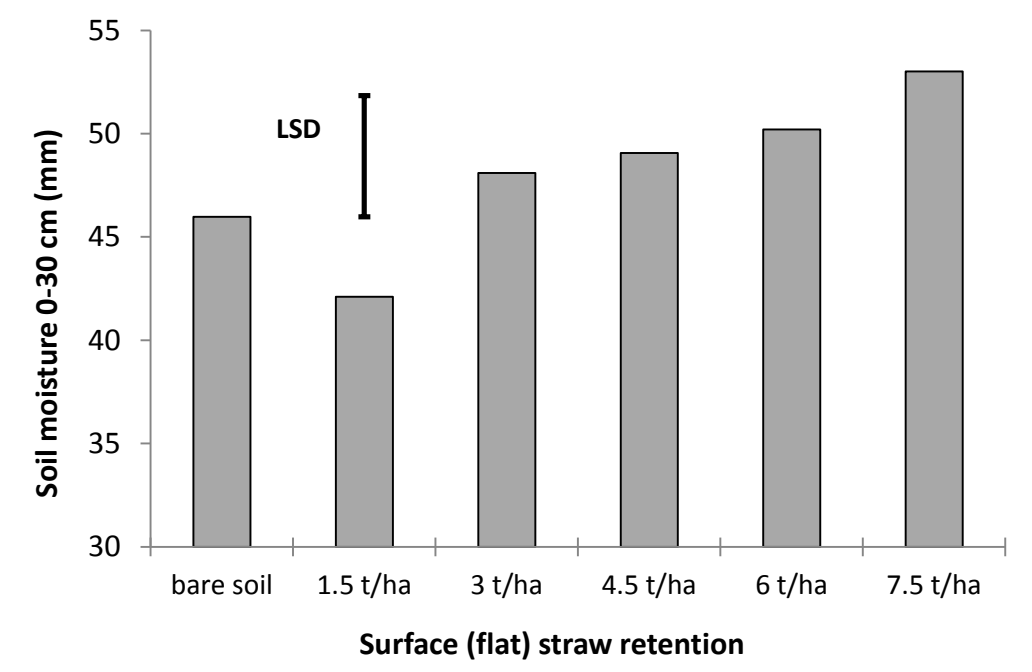

Figure 10. Soil moisture $(\mathrm{mm})$ at $0-30 \mathrm{~cm}$ depth under fallow plots with varying levels of surface residue retention 5 Aug. 2010.

located in the south of the station as compared to C16 in the north may in part be due to the slightly higher sand content in C16.

Soil organic carbon contents could be increased by reducing tillage and by retention of crop residues and organic matter recycling. In a previous study carried out at Tel Hadya, it was shown that SOC was significantly increased by application of large amounts $(10 \mathrm{Mg} / \mathrm{ha} / 2 \mathrm{yr})$ of compost and less intensive tillage [6]. However, production and availability of compost at such amounts exceeds the limits of biomass and manure production of this agro-ecosystem and thus is not a feasible option for farmers, unless compost is produced elsewhere and imported. The results of the current study show that under conditions more attractive and manageable for farmers in the region, namely when only part of the residues are retained, the increase in SOC, with around $0.28 \mathrm{Mg}$ $\mathrm{C} / \mathrm{ha} / \mathrm{yr}$, is very moderate. This figure comes very close to the independently derived C-sequestration rate $(0.27$ $\mathrm{Mg} / \mathrm{ha} / \mathrm{yr}$ ) by application of the crop-soil simulation model CropSyst [29]. Both studies show that the C sequestration achievable in these environments is neither attractive to farmers in terms of potential extra income by payment for environmental services—currently one ton of carbon is traded with a value less than US\$10 —nor 
will it put a notable dent into global C emissions or mitigation of climate change (compare also [14] [30]). Nevertheless, the increase in soil health by minimizing soil disturbance (ZT) and residue retention is noteworthy, and it must be assumed that improvements in soil chemical and physical characteristics are a direct response to increases in SOM.

In a similar study from Spain [31] assessed the impact of tillage (CT, minimum tillage , ZT) on soil quality indicators, but provided no quantitative results of the various analyses, focusing instead on a principal component analysis (PCA) for singling out the best indicator. The indicators with the greatest PCA loadings were penetration resistance, particulate organic matter $(\mathrm{POM})$ and $\mathrm{SOC}$ at $0-5 \mathrm{~cm}$, and aggregate stability and POM at 5 - 15-cm soil depth. Contrary to [31], we measured a significant impact of tillage on extractable P (a significant increase due to ZT). In line with Ibid. we saw an increase of aggregate stability and formation of more larger WSA under ZT, but not in all trials.

Higher extractable P-contents in the topsoil under NT compared to CT were found by [32] in a non-calcaric, acid soil in Central Spain under a summer-rainfall climate, and by [33] in a high pH, low SOM soil of northern India. The latter argue that higher (Olsen) extractable $\mathrm{P}$ contents are due to greater microbial activity-witnessed in our study by the increased microbial $\mathrm{N}$ content with ZT in B4-and reduction of the activities of P-fixing/immobilizing ions like $\mathrm{Ca}^{2+}, \mathrm{Fe}^{3+}$ and $\mathrm{Al}^{3+}$ by forming stable complexes with SOM. [34] reported that the distribution of $\mathrm{P}$ among fractions changed, with a higher concentration of labile inorganic $\mathrm{P}$ at the soil surface layer in NT than in CT in a long-term trial in Argentina (sub-humid climate; fine, mixed, thermic Typic Argiudol).

Soil mineral $\mathrm{N}$ contents varied greatly over time and depth and no significant impact of any of the applied treatments on mineral $\mathrm{N}$ could be shown. It is generally assumed that SOM mineralization and nitrate release are stimulated by tillage [35]-[37]. In our studies this could not be shown, probably because the organic matter contents and release of $\mathrm{N}$ were comparably small and thus system related differences were not visible against the general "noise" of spatial and temporal heterogeneity.

Determination of the impact of tillage on WSA did not result in a clear-cut trend suggesting that reduced tillage and residue retention would always increase aggregate stability, as has been proven elsewhere [38]-[42]. However, ambiguous results in regard to the influence of tillage and residue retention on WSA were also found by [43] for Western Kenyan cropping systems under integrated soil fertility management. A higher share of larger aggregates $(>0.5 \mathrm{~mm}$ ) under ZT (April 2009) points towards better soil structure, which in turn positively affects soil water infiltration and retention-witnessed by our results on these properties. Further, more large aggregates in C16 than in B4 was most likely a positive effect of the higher SOM content in C16, as SOM is the glue that holds aggregates together. However, our observations show that WSAs change with soil depth. To reveal the underlying mechanisms further research is required to fully understand the impact of tillage on WSA of the high-clay, montmorillonitic soils of northern Syria, which are typical for the Mediterranean region.

It was somewhat surprising that soil water infiltration capacity varied significantly over time, which basically meant, at least for the soils at ICARDA headquarters, that the applied method [28] did not give consistent results complying with what could be considered saturated hydraulic conductivity. Also, quantities were much higherat least a factor 10 - than $\mathrm{K}_{\mathrm{s}}$-values established for the same soil [44]. Nevertheless, the consistency of results provides evidence about the soil ameliorating impact of ZT and residue management. An increased water infiltration capacity allows water to infiltrate deeper into the soil and diminishes water runoff and thus soil erosion. This has been known for many years, and has been shown in many other comparable studies, such as in Germany [45], USA [46] [47], Australia [48] [49], Poland [50], Argentina [37], and Mexico [51]. On the other hand, [52] observed surface crusting and decreased water infiltration under NT. Yet, despite reduced infiltration, their NT treatments still conserved more soil moisture during the dry fallow period than the tilled plots. [53] also could not find any improvement in infiltration rate under ZT in comparison to chisel ploughing in Argentina.

We tried to answer the question whether in addition to higher water infiltration capacity by reduced tillage and (surface) residue management a surface residue layer would conserve soil moisture. During the late cropping season, high surface residue levels did not contribute to moisture conservation in the top $15 \mathrm{~cm}$ of soil, contradicting what has been reported elsewhere [22] [54] [55]. However, increased crop transpiration—manifesting itself in significantly higher yields compared to the off-site (non-irrigated) control—could have confounded the results. After harvest, under fallow conditions, residues could in general not prevent the loss of soil moisture from $0-15 \mathrm{~cm}$ depth within about four weeks although moisture levels were some few per cent higher during the first three weeks under the plots with the two highest residue levels. This means residue retention 
impacted moisture in the top soil for a limited time only. Under fallow conditions the effect was still notable five weeks after application of $30 \mathrm{~mm}$ of irrigation water when including $15-30 \mathrm{~cm}$ depth into the calculation, but only if very high amounts of residue $(7.5 \mathrm{Mg} / \mathrm{ha}$ ) were retained; much more than can be produced on-site under dry rainfed conditions. A temporary reduction of soil water evaporation during the cropping season when residues are retained should improve the crop-soil water balance by shifting water losses from unproductive evaporation to productive crop transpiration. However, a recent modelling study revealed that the impact is limited, not exceeding on average 10 - $15 \mathrm{~mm}$ per season that is transpired instead of evaporated [44].

Corresponding yield data [5] revealed that minimum tillage and residue retention translates into higher yields for all major crops of the region in the majority of years. Our data show that obviously this is due to the effect of an increased soil quality and more favorable (short-term) soil water relations. Adequate, balanced nutrient management including crop nutrition by chemical fertilizer application is, of course, an underlying necessity. Our results provide evidence that SOM increased in response to $\mathrm{N}$-fertilizer application, but further research is required to consolidate this observation.

\section{Conclusion}

In this study of rainfed cropping systems typical of Mediterranean northern Syria, reducing tillage and retaining crop residues promoted significant improvements in soil quality, as reflected by an increase in SOC, higher extractable P contents and improved soil water infiltration capacity, all of which are suitable indicators of soil quality changes under CA. However the positive changes in soil quality were not pronounced, similar to the accompanying increases in crop yields. This is not surprising, as productivity in the semiarid agro-ecosystems in northern Syria is constrained primarily by the limited and erratic rainfall. However, in combination with the economic savings - by reducing tillage, farmers save labor and money that would otherwise be invested in implements and tractor power-this type of conservation agriculture provides an attractive option for farmers in the West Asia and North Africa region, from the standpoints of both economy and ecological efficiency.

\section{Acknowledgements}

The authors wish to thank all ICARDA staff who contributed to this research, especially Jürgen Diekmann, Shukri Ismail, Shereen Baddour, Zainab Hamou, Fatima Hussein and Nezha Merjaneh. The mentioned studies in part were funded by ACIAR and AUSAID (Project no. CIM/2008/027), an internship of Lona van Delden with ICARDA was sponsored by The Agriculture and Environment Foundation (c/o Marlene and Jürgen Diekmann), Muhammad Ansar received funds from Rawalpindi Arid Agriculture University, Pakistan, and Kayoko Shimonaka was funded by the Tottori University and UNU, all of which is greatly appreciated.

\section{References}

[1] Zeder, M.A. (2008) Domestication and Early Agriculture in the Mediterranean Basin: Origins, Diffusion, and Impact. Proceedings of the National Academy of Science of the United States of America, 105, 11597-11604. http://dx.doi.org/10.1073/pnas.0801317105

[2] Smith, R.C.G. and Harris, H.C. (1981) Environmental Resources and Restraints to Agricultural Production in a Mediterranean-Type Environment. Plant Soil, 58, 31-57. http://dx.doi.org/10.1007/BF02180048

[3] Ryan, J., Singh, M. and Pala, M. (2008) Long-Term Cereal-Based Rotation Trials in the Mediterranean Region: Implications for Cropping Sustainability. Advances in Agronomy, 97, 273-319. http://dx.doi.org/10.1016/S0065-2113(07)00007-7

[4] Pala, M., Harris, H.C., Ryan, J., Makboul, R. and Dozom, S. (2000) Tillage Systems and Stubble Management in a Mediterranean-Type Environment in Relation to Crop Yields and Soil Moisture. Experimental Agriculture, 36, 232242. http://dx.doi.org/10.1017/S0014479700002052

[5] Piggin, C., Haddad, A. and Khalil, Y. (2011) Development and Promotion of Zero Tillage in Iraq and Syria. Proceedings of 5th World Congress on Conservation Agriculture, Brisbane, 26-29 September 2011, 304-305.

[6] Sommer, R., Ryan, J., Masri, S., Singh, M. and Diekmann, J. (2011) Effect of Shallow Tillage, Mouldboard Ploughing, Straw Management and Compost Addition on Soil Organic Matter and Nitrogen in a Dryland Barley/Wheat-Vetch Rotation. Soil \& Tillage Research, 115, 39-46. http://dx.doi.org/10.1016/j.still.2011.06.003

[7] Ryan, J., Sommer, R. and Ibrikci, H. (2012) Fertilizer Best Management Practices: A Perspective from the Dryland West Asia-North Africa Region. Journal of Agronomy and Crop Science, 198, 57-67. 
http://dx.doi.org/10.1111/j.1439-037X.2011.00488.x

[8] Derpsch, R. and Friedrich, T. (2009) Development and Current Status of No-Till Adoption in the World. Proceeding on CD. 18th Triennial Conference of the International Soil Tillage Research Organization (ISTRO), Izmir, 15-19 June 2009.

[9] Derpsch, R., Friedrich, T., Kassam, A. and Hongwen, L. (2010) Current Status of Adoption of No-Till Farming in the World and Some of Its Main Benefits. International Journal of Agricultural and Biological Engineering, 3, 1-25.

[10] Blevins, R.L. and Frye, W.W. (1993) Conservation Tillage: An Ecological Approach to Soil Management. Advances in Agronomy, 51, 33-78. http://dx.doi.org/10.1111/j.1439-037X.2011.00488.x

[11] Hobbs, P.R., Sayre, K. and Gupta, R. (2008) The Role of Conservation Agriculture in Sustainable Agriculture. Philosophical Transactions of the Royal Society B, 363, 543-555. http://dx.doi.org/10.1098/rstb.2007.2169

[12] Friedrich, T., Derpsch, R. and Kassam, A. (2012) Overview of the Global Spread of Conservation Agriculture. Field Actions Science Reports (Online), Special Issue 6. http://factsreports.revues.org/1941

[13] Lal, R. (2010) Beyond Copenhagen: Mitigating Climate Change and Achieving Food Security through Soil Carbon Sequestration. Food Security, 2, 169-177. http://dx.doi.org/10.1007/s12571-010-0060-9

[14] Sommer, R. and De Pauw, E. (2011) Soil carbon Sequestration-Can It Take the Heat of Global Warming? In: Solh, M. and Saxena, M.C., Eds., Food Security and Climate Change in Dry Areas: Proceedings of an International Conference, Amman, 1-4 February 2010, 291-298.

[15] Sommer, R. and Bossio, D. Dynamics and climate change mitigation potential of soil organic carbon sequestration. Submitted to British Journal of Environment and Climate Change.

[16] Mrabet, R., Moussadek, R., Fadlaoui, A. and van Ranst, E. (2012) Conservation Agriculture in Dry Areas of Morocco. Field Crops Research, 132, 84-94. http://dx.doi.org/10.1016/i.fcr.2011.11.017

[17] Thomson, E.F., Bahhady, F.A. and Martin, A. (1989) Sheep Husbandry at the Cultivated Margin of the North-West Syrian Steppe. International Center for Agricultural Research in the Dry Areas (ICARDA), Aleppo, $92 \mathrm{p}$.

[18] Rischkowsky, B., Thomson, E.F., Shnayien, R. and King, J.M. (2004) Mixed Farming Systems in Transition: The Case of Five Villages along a Rainfall Gradient in North-West Syria. Experimental Agriculture, 40, 109-126. http://dx.doi.org/10.1017/S0014479703001480

[19] Iñiguez, L. and Aw-Hassan, A. (2005) The Sheep and Goat Dairy Sector in Mediterranean West Asia and North Africa (WANA). Proceedings of an International Symposium, Zaragoza, 28-30 October 2004, 13-22.

[20] Nordblom, T.L. (1987) The Importance of Crop Residues as Feed Resources in West Asia and North Africa. In: Reed, J.D., Capper, B.S. and Neate, P.J.H., Eds., Plant Breeding and the Nutritive Value of Crop Residues: Proceedings of a Workshop Held at ILCA, Addis Ababa, 7-10 December 1987, 41-63.

[21] Magnan, N., Larson, D.M. and Taylor, J.E. (2012) Stuck on Stubble? The Non-Market Value of Agricultural Byproducts for Diversified Farmers in Morocco. American Journal of Agricultural Economics, 94, 1055-1069. http://dx.doi.org/10.1093/ajae/aas057

[22] Bescansa, P., Imaz, M.J., Virto, I., Enrique, A. and Hoogmoed, W.B. (2006) Soil Water Retention as Affected by Tillage and Residue Management in Semiarid Spain. Soil \& Tillage Research, 87, 19-27. http://dx.doi.org/10.1016/j.still.2005.02.028

[23] Ryan, J., Singh, M., Pala, M., Makhboul, R., Masri, S., Harris, H.C. and Sommer, R. (2010) Crop Sequences, Nitrogen Fertilizer and Grazing Intensity in Relation to Wheat Yields in Rainfed Systems. Journal of Agricultural Science, 148, 205-216. http://dx.doi.org/10.1017/S0021859609990566

[24] Ryan, J., Masri, S., Garabet, S., Diekmann, J. and Habib, H. (1997) Soils of ICARDA's Agricultural Experiment Stations and Sites: Climate, Classification, Physical and Chemical Properties, and Land Use. Technical Bulletin, International Center for Agricultural Research in the Dry Areas (ICARDA), Aleppo.

[25] Estefan, G., Sommer, R. and Ryan, J. (2014) Analytical Methods for Soil-Plant and Water in the Dry Areas. A Manual of Relevance to the West Asia and North Africa Region. 3rd Edition, International Center for Agricultural Research in the Dry Areas, Aleppo, 255 p.

[26] Shimonaka, K., Sommer, R. and Yamamoto, S. (2010) Effect of Tillage and Residue Management on Selected Soil Quality Indicators under Mediterranean Conditions. ASA-CSSA-SSSA 2010 Annual Meetings, Long Beach, 31 October3 November 2010.

[27] Shimonaka, K., Sommer, R. and Yamamoto, S. (2011) Characterization of Stable Soil Organic Fractions As Means Of Carbon Sequestration In Conservation Agriculture Systems Under Semi-Arid Mediterranean Region. International Workshop on Dryland Science for Food Security and Natural Resource Management under Changing Climate, Konya, 7-9 December 2011.

[28] Nimmo, J.R., Schmidt, K., Perkins, K.S. and Stock, J.D. (2009) Rapid Measurement of Field-Saturated Hydraulic 
Conductivity for Areal Characterization. Vadose Zone Journal, 8, 142-149. http://dx.doi.org/10.1017/S0021859609990566

[29] Sommer, R. and Ryan, J. (2009) Using the CropSyst Model for Assessing Soil Organic Carbon Sequestration of a Clayey Xerochrept under Continuous Wheat and Partial Residue Retention. 10th International Meeting on Soils with Mediterranean Type of Climate-Soil Conservation and Protection is the Basis for Sustainable Land Management, Beirut, 23-26 June 2009, 101-106.

[30] Sommer, R. and De Pauw, E. (2011) Organic Carbon in Soils of Central Asia-Status Quo and Potentials for Sequestration. Plant Soil, 338, 273-288. http://dx.doi.org/10.1007/s11104-010-0479-y

[31] Imaz, M.J., Virto, I., Bescansa, P., Enrique, A., Fernandez-Ugalde, O. and Karlen, D.L. (2010) Soil Quality Indicator Response to Tillage and Residue Management on Semi-Arid Mediterranean Cropland. Soil and Tillage Research, 107, 17-25. http://dx.doi.org/10.1016/j.still.2010.02.003

[32] López-Fando, C. and Almendros, G. (1995) Interactive Effects of Tillage and Crop Rotations on Yield and Chemical Properties of Semiarid Soil in Central Spain. Soil and Tillage Research, 36, 45-57. http://dx.doi.org/10.1016/0167-1987(95)00495-5

[33] Pradhan, P.R., Pandey, R.N., Behera, U.K., Swarup, A., Datta, S.C. and Dwivedi, B.S. (2011) Tillage and Crop Residue Management Practices on Crop Productivity, Phosphorus Uptake and Forms in Wheat (Triticum aestivum)-Based Cropping Systems. Indian Journal of Agricultural Sciences, 81, 1168-1173.

[34] Zamuner, E.C., Picone, L.I. and Echeverria, H.E. (2008) Organic and Inorganic Phosphorus in Mollisol Soil under Different Tillage Practices. Soil and Tillage Research, 99, 131-138. http://dx.doi.org/10.1016/j.still.2007.12.006

[35] Silgram, M. and Shepherd, M.A. (1999) The Effects of Cultivation on Soil Nitrogen Mineralization. Advances in Agronomy, 65, 267-311. http://dx.doi.org/10.1016/S0065-2113(08)60915-3

[36] Malhi, S.S., Grant, C.A., Johnston, A.M. and Gill, K.S. (2001) Nitrogen Fertilization Management for No-Till Cereal Production in the Canadian Great Plains: A Review. Soil and Tillage Research, 60, 101-122. http://dx.doi.org/10.1016/S0167-1987(01)00176-3

[37] Alvarez, R. and Steinbach, H.S. (2009) A Review of the Effects of Tillage Systems on Some Soil Physical Properties, Water Content, Nitrate Availability and Crops Yield in the Argentine Pampas. Soil and Tillage Research, 104, 1-15. http://dx.doi.org/10.1016/j.still.2009.02.005

[38] Hajabbasi, M.A. and Hemmat, A. (2000) Tillage Impacts on Aggregate Stability and Crop Productivity in a Clay-Loam Soil in Central Iran. Soil and Tillage Research, 56, 205-212. http://dx.doi.org/10.1016/S0167-1987(00)00140-9

[39] Mrabet, R., Saber, N., El-Brahli, A., Lahlou, S. and Bessam, F. (2001) Total, Particulate Organic Matter and Structural Stability of a Calcixeroll Soil under Different Wheat Rotations and Tillage Systems in a Semiarid Area of Morocco. Soil and Tillage Research, 57, 225-235. http://dx.doi.org/10.1016/S0167-1987(00)00180-X

[40] Chan, K.Y., Heenan, D.P. and Oates, A. (2002) Soil Carbon Fractions and Relationship to Soil Quality under Different Tillage and Stubble Management. Soil and Tillage Research, 63, 133-139. http://dx.doi.org/10.1016/S0167-1987(01)00239-2

[41] Hernanz, J.L., López, R., Navarrete, L. and Sánchez-Girón, V. (2002) Long-Term Effects of Tillage Systems and Rotations on Soil Structural Stability and Organic Carbon Stratification in Semiarid Central Spain. Soil and Tillage Research, 66, 129-141. http://dx.doi.org/10.1016/S0167-1987(02)00021-1

[42] Ayuke, F.O., Brussaard, L., Vanlauwe, B., Six, J., Lelei, D.K., Kibunja, C.N. and Pulleman, M.M. (2011) Soil Fertility Management: Impacts on Soil Macrofauna, Soil Aggregation and Soil Organic Matter Allocation. Applied Soil Ecology, 48, 53-62. http://dx.doi.org/10.1016/j.apsoil.2011.02.001

[43] Paul, B.K., Vanlauwe, B., Ayuke, F., Gassner, A., Hoogmoed, M., Hurisso, T.T., Koala, S., Lelei, D., Ndabamenye, T., Six, J. and Pulleman, M.M. (2013) Medium-Term Impact of Tillage and Residue Management on Soil Aggregate Stability, Soil Carbon and Crop Productivity. Agriculture, Ecosystems \& Environment, 164, 14-22. http://dx.doi.org/10.1016/j.agee.2012.10.003

[44] Sommer, R., Piggin, C., Haddad, A., Hajdibo, A., Hayek, P. and Khalil, Y. (2012) Simulating the Effects of Minimum Tillage and Crop Residue Retention on Water Relations and Yield of Wheat under Rainfed Semiarid Mediterranean Conditions. Field Crops Research, 132, 40-52. http://dx.doi.org/10.1016/j.fcr.2012.02.024

[45] Ehlers, W. (1975) Observations on Earthworm Channels and Infiltration on Tilled and Untilled Loess Soil. Soil Science, 119, 242-249. http://dx.doi.org/10.1097/00010694-197503000-00010

[46] Dao, T.H. (1993) Tillage and Winter Wheat Residue Management Effects on Water Infiltration and Storage. Soil Science Society of America Journal, 57, 1586-1595. http://dx.doi.org/10.2136/sssaj1993.03615995005700060032x

[47] Hatfield, J.L., Sauer, T.J. and Prueger, J.H. (2001) Managing Soils to Achieve Greater Water Use Efficiency. Agronomy Journal, 93, 271-280. http://dx.doi.org/10.2134/agronj2001.932271x 
[48] Bissett, M.J. and O’Leary, G.J. (1996) Effects of Conservation Tillage and Rotation on Water Infiltration in Two Soils in South-Eastern Australia. Australian Journal of Soil Research, 34, 299-308. http://dx.doi.org/10.1071/SR9960299

[49] Zhang, S.L., Simelton, E., Lovdahl, L., Grip, H. and Chen, D.L. (2007) Simulated Long-Term Effects of Different Soil Management Regimes on the Water Balance in the Loess Plateau, China. Field Crops Research, 100, 311-319. http://dx.doi.org/10.1016/j.fcr.2006.08.006

[50] Lipiec, J., Kuś, J., Słowińska-Jurkiewicz, A. and Nosalewicz, A. (2006) Soil Porosity and Water Infiltration as Influenced by Tillage Methods. Soil and Tillage Research, 89, 210-220. http://dx.doi.org/10.1016/j.still.2005.07.012

[51] Verhulst, N., Govaerts, B., Verachtert, E., Castellanos-Navarrete, A., Mezzalama, M., Wall, P., Deckers, J. and Sayre, K.D. (2010) Conservation Agriculture, Improving Soil Quality for Sustainable Production Systems? In: Lal, R. and Stewart, B.A., Eds., Advances in Soil Science: Food Security and Soil Quality, CRC Press, Boca Raton, 137-208.

[52] Jones, O. Hauser, V.L. and Popham, T.W. (1994) No-Tillage Effects on Infiltration, Runoff, and Water Conservation on Dryland. Transactions of the ASABE, 37, 473-479. http://dx.doi.org/10.13031/2013.28099

[53] Sasal, M.C., Andriuloa, A.E. and Taboada, M.A. (2006) Soil Porosity Characteristics and Water Movement under Zero Tillage in Silty Soils in Argentinian Pampas. Soil and Tillage Research, 87, 9-18. http://dx.doi.org/10.1016/j.still.2005.02.025

[54] Sommer, R., Wall, P.C. and Govaerts, B. (2007) Model-Based Assessment of Maize Cropping under Conventional and Conservation Agriculture in Highland Mexico. Soil and Tillage Research, 94, 83-100. http://dx.doi.org/10.1016/j.still.2006.07.007

[55] Verhulst, N., Nelissen, V., Jespers, N., Haven, H., Sayre, K.D., Raes, D., Deckers, J. and Govaerts, B. (2011) Soil Water Content, Maize Yield and Its Stability as Affected by Tillage and Crop Residue Management in Rainfed Semi-Arid Highlands. Plant and Soil, 344, 73-85. http://dx.doi.org/10.1007/s11104-011-0728-8 